1 Submitted, accepted and published by:

2 International Journal of Greenhouse Gas Control (2014) Vol. 22, pp. 15-24.

3

\title{
Release of pollutant components in CLC of lignite
}

5

6 T. Mendiara*, M.T. Izquierdo, A. Abad, L. F. de Diego, F. García-Labiano, P. Gayán, J.

Adánez

Department of Energy and Environment, Instituto de Carboquímica-ICB-CSIC

Miguel Luesma Castán 4, 50018, Zaragoza, Spain

10

tmendiara@icb.csic.es

11

12

13

14

15

16

17

18

$19 *$ Corresponding author:

20 Phone: + 34976733 977;

$21 \quad$ Fax: +34 976733318 


\section{Abstract}

23 The recently developed Chemical Looping Combustion technology (CLC) is nowadays

24 considered an interesting option to capture $\mathrm{CO}_{2}$ at low cost in fossil fuelled power plants. In

25 the past years, significant advances have been achieved in the combustion of both gaseous

26 and solid fuels. Nevertheless, pollutant gas emissions from CLC systems have received little

27 attention. This paper focuses on sulphur, nitrogen and mercury emissions during lignite

28 combustion in a $500 \mathrm{~W}_{\text {th }}$ CLC unit. Ilmenite was used as oxygen carrier, as it is one of the most common materials used for CLC of solid fuels. The main sulphur species detected in the fuel reactor were $\mathrm{H}_{2} \mathrm{~S}$ and $\mathrm{SO}_{2}$. The amount and proportion depended on the temperature of

31 the fuel reactor. The higher the temperature, the more $\mathrm{H}_{2} \mathrm{~S}$ converted to $\mathrm{SO}_{2}$. In the air reactor, the sulphur in the unconverted char was released as $\mathrm{SO}_{2}$. Regarding the emission of nitrogen in coal, most of the nitrogen was found as $\mathrm{N}_{2}$ at the outlet of the fuel reactor. No $\mathrm{NH}_{3}$ or $\mathrm{HCN}$ were registered and only small amounts of $\mathrm{NO}$ were detected. The nitrogen contained in the char reaching the air reactor was released as NO. Mercury speciation was also analyzed and the ratio $\mathrm{Hg}^{2+} / \mathrm{Hg}^{0}$ determined. In the fuel reactor, the major mercury species was $\mathrm{Hg}^{0}$ and in the air reactor $\mathrm{Hg}^{2+}$. The incorporation of a carbon separation unit between fuel and air reactors would help to reduce the sulphur emissions in the air reactor and comply with the current legislation for power generation systems.

46 Keywords: combustion, coal, $\mathrm{CO}_{2}$ capture, chemical looping, ilmenite, emissions 


\section{Introduction}

48

49 In recent years, the concentration of different greenhouse gases in the atmosphere has increased significantly compared to pre-industrial levels. The major contribution to this increment corresponds to carbon dioxide (IPCC, 2007). The increase of $\mathrm{CO}_{2}$ atmospheric concentration has been linked to global warming and this fact has awoken the interest in the mitigation of its emission. New technologies have been developed to facilitate $\mathrm{CO}_{2}$ capture and subsequent storage (CCS). Chemical Looping Combustion (CLC) is an emerging technology which allows $\mathrm{CO}_{2}$ capture from power plants at low cost (Eide et al., 2005). The process is based on the oxygen transfer from air to fuel by means of a solid oxygen carrier avoiding direct contact between fuel and air. The oxygen carrier is normally a metal oxide.

The most common configuration for chemical looping combustion is two interconnected

fluidized beds, identified as fuel and air reactors, with the oxygen carrier material circulating between them. In the fuel reactor, the combustion of the fuel takes place while the oxygen carrier is reduced, yielding $\mathrm{CO}_{2}$ and water. Once water is condensed, the outlet gas of the fuel reactor consists of an almost pure $\mathrm{CO}_{2}$ stream. The reduced oxygen carrier is then transferred to the air reactor, where it is re-oxidized in air so that a new redox cycle can be started.

CLC allows the combustion of both gaseous and solid fuels. There are two alternatives to burn a solid fuel in a CLC system. In the first, the solid fuel is gasified in-situ in the fuel reactor using steam or $\mathrm{CO}_{2}$ as fluidization agents and the oxygen carrier particles react with the gaseous products of coal devolatilization/gasification (Cao et al., 2006). In the second, the

69 solid fuel is burned with the gaseous oxygen released by the oxygen carrier in the fuel reactor. This process is referred as Chemical Looping with Oxygen Uncoupling (CLOU)

71 (Mattisson et al., 2009). This paper focuses on the first alternative, denoted as $i \mathrm{G}$-CLC. 
72 Recent research activities in $i \mathrm{G}-\mathrm{CLC}$ have been focused on three main aspects. The first one

is finding the adequate oxygen carrier. Some oxygen carrier losses are expected in the drainage of fuel ashes. Therefore, low-cost oxygen carriers are preferred. From the studies performed until now, Fe-based minerals or industrial residues are the most promising candidates. Among them, ilmenite has been commonly used (Adánez et al., 2012). The second aspect is the optimization of the fuel gasification, as it is already known that the gasification of the solid fuel is the limiting step of this process (Dennis et al., 2006; Leion et al., 2007; Cuadrat et al., 2011). The presence of unconverted char in the solid stream at the fuel reactor outlet implies a decrease in the carbon capture efficiency of the process. Once the char reaches the air reactor, it is burnt there releasing $\mathrm{CO}_{2}$ that is not captured. Therefore, char conversion in the fuel reactor should be as high as possible. One of the options already being investigated is the incorporation of a carbon separation unit between fuel and air reactors where unconverted char could be separated from the oxygen carrier particles and recirculated back to the fuel reactor (Cao et al., 2006). Finally, the minimization of unburned products at the fuel reactor outlet is another focus of interest. The presence of unburned compounds reduces the energetic efficiency of the CLC process. The use of an oxygenpolishing step downstream where pure oxygen would be used to burn these compounds is a widespread solution, although some other alternatives are possible (Gayán et al., 2013).

\subsection{Pollutants in coal combustion: $\mathrm{S}, \mathrm{N}$ and $\mathrm{Hg}$}

Another important aspect during the combustion process is the fate of different elements commonly present in coal which can lead to pollutant formation, such as sulfur, nitrogen or mercury. Traditionally, three different types of sulfur can be considered in coal: pyritic, sulphate (disulfides and sulfates) and organic sulfur (bond to the hydrocarbon matrix). The amount of organic sulfur is dependent on the coal rank although it is usually one-half to onethird of the total sulfur. At high temperatures, most of the sulfur in coal is released as $\mathrm{H}_{2} \mathrm{~S}$ and 
$97 \mathrm{CS}_{2}$ (Attar, 1978). Further oxidation of these species leads to $\mathrm{SO}_{2}$ formation, which has been found to be responsible for the acid rain. During the coal particle devolatilization, fuel-N is distributed between volatiles and char. The distribution of nitrogen between char and volatiles, as well as the volatile composition, depends mainly on the fuel structure and the temperature (Glarborg et al., 2003). At temperatures typical for fluidized bed combustion, $\mathrm{HCN}$ together with $\mathrm{NH}_{3}$ and $\mathrm{HNCO}$ can be released during pyrolysis from fuel-bound nitrogen, in particular for low rank coals and biomass. These species can be oxidized to $\mathrm{NO}_{\mathrm{x}}$ or, depending on the stoichiometry or fuel-N concentration, they may be converted to $\mathrm{N}_{2}$ (Glarborg et al., 2003). The collective term $\mathrm{NO}_{\mathrm{x}}$ represents $\mathrm{NO}, \mathrm{NO}_{2}$ and $\mathrm{N}_{2} \mathrm{O}$. Nitric oxide and nitrogen dioxide are also acid rain precursors and participate in the generation of

107 photochemical smog, while nitrous oxide is a greenhouse gas. During conventional combustion processes, mercury in coal evaporates yielding $\mathrm{Hg}^{0}, \mathrm{HgO}$ and $\mathrm{HgCl}_{2}$. The amount of each species in the gas phase depends on how the mercury is bonded in coal and on the compounds also present in the gaseous stream, mainly particulates and chlorine (Olson and

111 Mibeck, 2005). $\mathrm{Hg}^{0}$ is the thermodynamically stable form in the highest temperature regions

112 of combustors and gasifiers and remains the dominant form in the relatively reducing

113 conditions of a gasification flue gas. If temperature decreases, $\mathrm{Hg}^{0}$ will react to form $\mathrm{Hg}^{2+}$

114 compounds (Galbreath and Zygarlicke, 1996). In case of existence of a wet flue gas

115 desulphurization unit (FGD), the oxidized mercury would be removed there. $\mathrm{Hg}^{0}$ is more

116 difficult to control because of its high vapour pressure and low water solubility. Once emitted

117 through the stack, it may remain in the atmosphere and is likely to enter the food chain with 118 the risk of affecting human health.

\section{$119 \quad 1.2$ The relevance of pollutants in CLC}

120 Compared to conventional combustion, the concern about $\mathrm{H}_{2} \mathrm{~S}, \mathrm{SO}_{2}, \mathrm{NO}_{\mathrm{x}}$ and $\mathrm{Hg}^{0} / \mathrm{Hg}^{2+}$

121 formation in CLC systems is not only environmental but also operational. Two gaseous 
122 streams exit from an $i \mathrm{G}$-CLC unit: (i) a $\mathrm{CO}_{2}$-concentrated stream from the fuel reactor and

123 (ii) a lean-air stream from the air reactor. Char in the fuel reactor is gasified while char in the

124 air reactor is burned. This difference can affect the release of pollutants in both reactors. The

125 presence of pollutants in the gas stream from the air reactor can be managed similarly to the

126 case of conventional combustion. The gaseous outlet stream from the air reactor is emitted

127 directly to the atmosphere. This means that the amounts of sulphur, nitrogen and mercury

128 compounds exiting the air reactor should comply with the current legislation for pollutant

129 emissions from power generation systems. In the Directive 2010/75/UE, the limit for $\mathrm{SO}_{2}$ and

$130 \mathrm{NO}_{\mathrm{x}}$ emission from power generation plants burning solid fuels up to $300 \mathrm{MW}_{\text {th }}$ is set to 200

$131 \mathrm{mg} / \mathrm{Nm}^{3}\left(6 \% \mathrm{O}_{2} \mathrm{vd}\right.$.). The only reference for mercury can be found in this Directive for

132 incineration systems. In this case, the maximum mercury emission is set to $0.05 \mathrm{mg} / \mathrm{Nm}^{3}$

133 (normalized to $10 \% \mathrm{O}_{2}$ vd. in the outlet stream).

134

135 The presence of other components than $\mathrm{CO}_{2}$ (not only pollutants) in the $\mathrm{CO}_{2}$ stream is

136 important regarding the quality of the $\mathrm{CO}_{2}$. The final composition of the $\mathrm{CO}_{2}$ stream depends

137 on the fuel, the combustion technology and the $\mathrm{CO}_{2}$ capture process used (post-combustion,

138 pre-combustion and oxyfuel capture) (Anheden et al., 2004). In order to lay out

139 recommendations about $\mathrm{CO}_{2}$ quality not only the origin of the captured $\mathrm{CO}_{2}$ but also the

140 transportation means (pipeline, shipping) and the storage location (geological or ocean

141 storage) should be taken into account. Some of the first specifications for $\mathrm{CO}_{2}$ quality were

142 intended for Enhanced Oil Recovery (EOR) applications. The specifications for the $\mathrm{CO}_{2}$

143 stream were case-specific. The Weyburn Pipeline (IPCC, 2005) and Gullfalks ${ }^{1}$ experiences

\footnotetext{
${ }^{1} \mathrm{CO} 2$ supply report: document prepared by Elsam A/S, Kinder Morgan $\mathrm{CO}_{2}$ Company L.P.,NewEnergyStatoil http://www.co2.no/download.asp?DAFID=17\&DAAID=6.
} 
can be cited as examples. The European project ENhaced CAPture of $\mathrm{CO}_{2}(\mathrm{ENCAP})^{2}$

updated the knowledge gained during last years and presented a guideline about $\mathrm{CO}_{2}$ quality.

146 More recently, the work conducted as a part of the Euroepan $6^{\text {th }}$ Framework Programme

147 DYNAMIS ${ }^{3}$ completed the guidelines summarized in the ENCAP project giving new

148 recommended values for the other components found in the $\mathrm{CO}_{2}$ stream (de Visser et al.,

149 2008). In this case, the recommendations were intended for pipeline transportation. Table 1

150 shows the specifications given for different components.

152 The presence of other compounds in $\mathrm{CO}_{2}$ streams is associated with additional energy

153 requirements in the $\mathrm{CO}_{2}$ transport and storage chain. These compounds may shift the

154 boundary of the two-phase region to higher pressures and therefore higher operating pressures are required to maintain $\mathrm{CO}_{2}$ in dense phase (de Visser et al., 2008). The transport capacity would be also reduced because these impurities occupy volume. Moreover, the

157 impurities would lower the $\mathrm{CO}_{2}$ density and therefore the storage capacity. Other effects of

158 the presence of other compounds in the $\mathrm{CO}_{2}$ stream are the risk of corrosion and hydrate

159 formation, together with free water formation (EASAC, 2013). Mercury is known to

160 accumulate and attack aluminium components. Corrosion can be also caused when $\mathrm{CO}_{2}$ or

$161 \mathrm{H}_{2} \mathrm{~S}$ are dissolved in water forming carbonic and hydrosulfuric acid, respectively. Actually,

162 the joint presence of $\mathrm{CO}_{2}$ and $\mathrm{H}_{2} \mathrm{~S}$ is more corrosive than $\mathrm{H}_{2} \mathrm{~S}$ alone (de Visser et al., 2008).

163 Besides, $\mathrm{H}_{2} \mathrm{~S}, \mathrm{CO}_{2}$ and $\mathrm{CH}_{4}$ can form hydrates with water which can plug the line and cause

164 damage equipment. Regarding free water formation, there is no general agreement on the

165 limit for water content in the $\mathrm{CO}_{2}$ stream. Water content should be controlled more strictly

166 when $\mathrm{CO}_{2}$ is transported at low temperatures and pressures (de Visser et al., 2008). Besides

\footnotetext{
${ }^{2}$ ENCAP project. Enhanced capture of $\mathrm{CO}_{2} .6^{\text {th }}$ framework program. Contract number: SES6-CT-2004-502666. http://www.encapco2.org/index.htm

${ }^{3}$ Website DYNAMIS www.dynamis-hypogen.com
} 
167 the operational issues highlighted above, health and safety considerations are also important

168 when toxic compounds are present in the $\mathrm{CO}_{2}$ stream. In case of sudden leakages of the

169 transportation pipeline, the release to the atmosphere of compounds such as $\mathrm{H}_{2} \mathrm{~S}$ or $\mathrm{CO}$

170 represents a risk due to their toxicity. The limit values for their concentration in the $\mathrm{CO}_{2}$

171 stream were also set to control the airborne concentration of the toxic compounds (de Visser

172 et al., 2008). As it can be observed in Table 1, despite the high toxicity of mercury no

173 recommendations for the mercury content in the $\mathrm{CO}_{2}$ stream are included.

174

175 Sulfur, nitrogen and mercury emissions from solid fuel fired systems have been largely

176 investigated under conventional combustion conditions during the last decades, but pollutant

177 emission in CLC combustion of solid fuels has received little coverage in literature (Shen et

178 al., 2010; Song et al., 2012, 2013). Shen et al. (2010) used a NiO/ $\mathrm{Al}_{2} \mathrm{O}_{3}$ oxygen carrier to

179 burn coal in a $1 \mathrm{~kW}_{\text {th }}$ prototype. They analyzed sulfur emissions both in fuel and air reactors

180 and observed that a high fuel reactor temperature favored $\mathrm{H}_{2} \mathrm{~S}$ transformation to $\mathrm{SO}_{2}$. The

181 increase of $\mathrm{SO}_{2}$ in the fuel reactor accelerated the reaction of $\mathrm{SO}_{2}$ to form $\mathrm{COS}$. Moreover

182 COS concentration in the fuel reactor increased with the fuel reactor temperature. In the air

183 reactor, the exit gas contained $\mathrm{SO}_{2}$ from the unconverted char being burned and from $\mathrm{Ni}_{3} \mathrm{~S}_{2}$

184 oxidation. This sulfide is formed in the fuel reactor due to the reaction of $\mathrm{H}_{2} \mathrm{~S}$ with $\mathrm{NiO}$,

185 especially at high temperatures. Although Shen et al. (2010) point to a regeneration of the

186 oxygen carrier in the air reactor, other authors indicated that part of the sulphur remained in

187 the solid and total regeneration was not possible (Dueso et al., 2012). This fact together with

188 the high toxicity of the nickel makes that Ni-based oxygen carriers were not considered

189 suitable for $i \mathrm{G}-\mathrm{CLC}$. Compared to nickel, the use of $\mathrm{Cu}$ - or Fe-based oxygen carriers could

190 reduce sulphur emissions from the air reactor (Forero et al., 2010; Cabello et al., 2013). Song

191 et al. $(2012,2013)$ studied the fate of fuel-N in experiments with anthracite and bituminous 
192 coal using two different oxygen carriers, i.e. $\mathrm{NiO} / \mathrm{Al}_{2} \mathrm{O}_{3}$ and hematite. They concluded that

$193 \mathrm{~N}_{2}$ was the only product of nitrogen transfer from fuel-N in the fuel reactor due to NO

194 reduction and the consumption of $\mathrm{NO}_{\mathrm{x}}$ precursors $\left(\mathrm{HCN}\right.$ and $\left.\mathrm{NH}_{3}\right)$. They observed that the

195 concentration of $\mathrm{N}_{2}$ in the fuel reactor exit gas increased with the fuel reactor temperature.

196 They also analyzed $\mathrm{NO}_{\mathrm{x}}$ emissions in the air reactor and determined that the proportion of

197 char-N converted to NO in the air reactor slightly increased when the fuel reactor temperature

198 increased from 850 to $950^{\circ} \mathrm{C}$. To date, the fate of mercury in a CLC system has not been

199 analyzed. Therefore no information about mercury speciation in CLC is already available in

200 literature.

$201 \quad 1.3$ Objective

202 The objective of the present work is the evaluation of the distribution of sulphur, nitrogen and mercury between fuel and air reactors during $i \mathrm{G}-\mathrm{CLC}$ of Spanish lignite together with the identification of the main species in the gaseous streams. Lignite was chosen as fuel due to its high reactivity and high sulphur content. The measurement of the different pollutants will be performed simultaneously, which is the novelty of this work compared to others available in literature. This will allow to consider for the first time the synergetic effects that may be present. Besides, an evaluation of the measures needed to fulfil pollutant emission laws and attain certain $\mathrm{CO}_{2}$ quality will be done based on the results obtained in the continuous unit.

\section{2. Experimental}

\section{$212 \quad 2.1$ Materials used}

213 Ilmenite has been one of the most used oxygen carriers for in situ gasification-CLC of coal

214 (Berguerand and Lyngfelt, 2008; Bidwe et al., 2011; Cuadrat et al., 2011; Schwebel et al.,

215 2012). The ilmenite used in this work was provided by the Norwegian company Titania A/S

216 and was extracted from a natural ore. The active phases in ilmenite are $\mathrm{Fe}_{2} \mathrm{O}_{3}$ and $\mathrm{Fe}_{2} \mathrm{TiO}_{5}$. 
217 The ilmenite was received in its reduced form, $\mathrm{FeTiO}_{3}$. Therefore it was calcined in air at

$218950^{\circ} \mathrm{C}$ during 24 hours to ensure complete oxidation. Then it was sieved to a particle size of

$219+100-300 \mu \mathrm{m}$. An increase in ilmenite reactivity has been observed with the number of redox

220 cycles (Cuadrat et al., 2011). Thus, the sample used in this work was previously activated so

221 that the reactivity of ilmenite during all the tests can be considered as constant. The main

222 properties of the activated ilmenite used are summarized in Table 2. Spanish lignite $(+200-$

$223300 \mu \mathrm{m}$ ) was used as fuel in the experiments. Table 3 shows the proximate and ultimate

224 analyses of the coal together with the low heating value.

$225 \quad 2.2$ Experimental setups and procedures

$226 \quad$ 2.2.1 Continuous unit

227 The coal combustion experiments were performed at the ICB-CSIC-s1 unit, previously used

228 in other works from our research group. The scheme of the setup is presented in Figure 1.

229 Detailed description of the experimental unit can be found elsewhere (Cuadrat et al., 2011).

230

231 In the present experiments, the ilmenite inventory introduced at the beginning of the

232 experiments was $3.3 \mathrm{~kg}$, corresponding to $0.7 \mathrm{~kg}$ of ilmenite in the fuel reactor. The steam

233 flow to the fuel reactor was $200 \mathrm{~L}_{\mathrm{N}} / \mathrm{h}$, corresponding to a velocity of $0.14 \mathrm{~m} / \mathrm{s}$ at $900^{\circ} \mathrm{C}$. In the

234 air reactor the total primary air flow was $1800 \mathrm{~L}_{\mathrm{N}} / \mathrm{h}$ (corresponding to a velocity of $0.45 \mathrm{~m} / \mathrm{s}$

235 at $\left.900^{\circ} \mathrm{C}\right)$. The secondary air flow was $400 \mathrm{~L}_{\mathrm{N}} / \mathrm{h}$. The nitrogen flow in the loop seal was 100

$236 \mathrm{~L}_{\mathrm{N}} / \mathrm{h}$. Lignite feeding rate was about $50 \mathrm{~g} / \mathrm{h}$, which determines a steam to carbon molar ratio

237 of 3.5 during the experiments. In order to measure the circulation flow rate of the oxygen

238 carrier, a diverting solid valve (6) at the outlet of the cyclone after the air reactor was placed.

239 Using this valve, the circulation flow rate was measured and controlled to be about $7 \mathrm{~kg} / \mathrm{h}$.

240 These conditions ensure that the operation is over stoichiometric conditions, so that there is

241 enough oxygen supply by the oxygen carrier. The oxygen carrier to fuel ratio $(\phi)$ is 
commonly used to compare the oxygen supplied by the circulating oxygen carrier to the oxygen needed to burn the fuel:

$\phi=\frac{\dot{m}_{O C} \cdot R_{O C}}{\Omega_{S F}}$

244 In this case, values of $\phi$ around 3 were used in the experiments. During operation,

245 temperatures in the fuel reactor bed and freeboard, air reactor bed and riser were monitored as

246 well as the pressure drops in selected points in the system, such as the fuel reactor bed, the air

247 reactor bed and the loop seal. The temperature in the air reactor was maintained at around

$248950^{\circ} \mathrm{C}$ and the fuel reactor temperature was varied from 875 to $930^{\circ} \mathrm{C}$. The fuel reactor

249 freeboard was kept constant at about $910^{\circ} \mathrm{C}$ in all the experiments. A total of 35 hours of

250 continuous operation feeding fuel and 55 hours of continuous fluidization were registered.

$251 \mathrm{CO}, \mathrm{CO}_{2}, \mathrm{H}_{2}$, and $\mathrm{CH}_{4}$ concentration in the fuel reactor outlet stream and $\mathrm{CO}, \mathrm{CO}_{2}$ and $\mathrm{O}_{2}$ at

252 the air reactor outlet were determined. The analyzers used in the measurements are included

253 in Table 4. The analysis of sulphur, nitrogen and mercury species required different

254 instrumentation, also included in Table 4. Oxidized mercury was retained in $\mathrm{KCl}$ impingers

255 with $1 \mathrm{M} \mathrm{KCl}$ placed in a bath at $0^{\circ} \mathrm{C}$ (Ontario Hydro Method). Sampling of gaseous mercury

$256\left(\mathrm{Hg}^{0}\right.$ and $\left.\mathrm{Hg}^{2+}\right)$ was performed during 30 minutes at steady state.

\subsubsection{Batch fluidized bed}

Some experiments were performed in order to better understand sulphur release in the

continuous unit and especially the fate of the pyritic sulphur in lignite. The release of sulphur

260 from lignite during pyrolysis and gasification processes under conditions similar to those in

261 the fuel reactor of the CLC unit was analyzed in a batch fluidized bed reactor. Details about

262 the fluidized reactor can be found elsewhere (Mendiara et al., 2013). The reactor was loaded

with $300 \mathrm{~g}$ of silica sand $(+200-300 \mu \mathrm{m})$ which act as an inert. The lignite coal $(20 \mathrm{~g})$ was

264 introduced in the silica sand bed with the help of a fuel chute. The temperature in the bed was

265 increased up to $900^{\circ} \mathrm{C}$ at $20 \mathrm{~K} / \mathrm{min}$ in nitrogen atmosphere $\left(200 \mathrm{~L}_{\mathrm{N}} / \mathrm{h}\right)$ and the products 
resulting from lignite pyrolysis were burned in a post-combustion chamber located after the

267 fluidized bed reactor. The combustion of the volatiles in this chamber took place at $800^{\circ} \mathrm{C}$ and $10 \% \mathrm{O}_{2}$. After condensing the steam, the resulting products were sent for analysis. Once the temperature reached $900^{\circ} \mathrm{C}$, the fluidizing agent was changed from nitrogen to steam. The products of char gasification at $900^{\circ} \mathrm{C}$ were then burned in the post-combustion chamber and the products registered. Char gasification lasted until no $\mathrm{CO}_{2}$ signal could detected in the product gas. Then, steam was replaced by air in order to burn any char that could still remain in the bed.

\section{Results and Discussion}

\subsection{CLC performance: carbon capture and combustion efficiency}

The objective of this work is to further investigate the fate of sulphur, nitrogen and mercury in coal in an $i \mathrm{G}-\mathrm{CLC}$ unit. Prior to any other analysis, the performance of the $i \mathrm{G}-\mathrm{CLC}$ system burning Spanish lignite with ilmenite as oxygen carrier was evaluated. The main compound at the fuel reactor outlet was $\mathrm{CO}_{2}$ and its percentage in the product stream increased with temperature. In all cases the $\mathrm{CO}_{2}$ concentration was below $90 \%\left(\mathrm{~N}_{2}\right.$ free dry basis). Unburned compounds, mainly $\mathrm{CO}, \mathrm{H}_{2}$ and $\mathrm{CH}_{4}$ were also detected. The total oxygen demand $\left(\Omega_{T}\right)$ compares the oxygen required to fully oxidize unconverted gaseous compounds in the fuel reactor with the oxygen required to burn the coal fed to $\mathrm{CO}_{2}$ and $\mathrm{H}_{2} \mathrm{O}$. As unconverted compounds $\mathrm{H}_{2}, \mathrm{CO}, \mathrm{CH}_{4}$ and $\mathrm{H}_{2} \mathrm{~S}$ are considered. The total oxygen demand allows a fast evaluation of the amount of oxygen that would be required to reduce the unburned in the fuel reactor stream in an oxygen polishing step.

$$
\Omega_{T}=\frac{0.5 \cdot F_{C O, F R}+2 \cdot F_{C_{4}, F R}+0.5 \cdot F_{H_{2}, F R}+1.5 \cdot F_{H_{2} S, F R}}{\left(\dot{m}_{S F} \cdot \Omega_{S F} / M_{O_{2}}\right)}
$$

The total oxygen demand values are presented in Figure 2. The oxygen demand decreased 
demand reported by Cuadrat et al. (2012) was larger, between $7-8 \%$ in the $870-920^{\circ} \mathrm{C}$ temperature range. This is due to the different solid inventories used by Cuadrat et al. (2012) $\left(1770 \mathrm{~kg} / \mathrm{MW}_{\text {th }}\right)$ and that used in the present experiments $\left(2700 \mathrm{~kg} / \mathrm{MW}_{\text {th }}\right)$. The ilmenite supplies a larger amount of oxygen in the fuel reactor which contributes to a better combustion of $\mathrm{CO}, \mathrm{H}_{2}$ and $\mathrm{CH}_{4}$.

Some carbon is emitted in the air reactor as $\mathrm{CO}_{2}$, corresponding to the char particles with low residence time in the fuel reactor to be gasified. The char conversion in the fuel reactor $\left(X_{\text {char }}\right)$ was calculated as the fraction of carbon in the char which is released to the fuel reactor exhaust gas stream:

$$
X_{\text {char }}=\frac{\left[F_{\mathrm{CO}_{2}, \mathrm{FR}}+F_{\mathrm{CO}, \mathrm{FR}}+F_{\mathrm{CH}_{4}, \mathrm{FR}}-F_{C, \mathrm{vol}}\right]}{\left[F_{\mathrm{CO}_{2}, \mathrm{FR}}+F_{\mathrm{CO}, \mathrm{FR}}+F_{\mathrm{CH}_{4}, F R}+F_{\mathrm{CO}_{2}, A R}-F_{C, \mathrm{vol}}\right]}
$$

301 The gasified char in the fuel reactor was calculated as the difference between the carbon in

302 the outlet gases of the fuel reactor and the carbon flow coming from the volatile matter, $F_{C, v o l}$.

303 The carbon content in the volatiles is directly calculated using the ultimate and proximate analysis of the coal as the difference between the total carbon in coal and the fixed carbon. The carbon captured in an $i \mathrm{G}-\mathrm{CLC}$ system depends on the carbon contained in the volatiles and the carbon in the char converted. The carbon capture efficiency $\left(\eta_{C C}\right)$ represents the

307 removal of carbon that would otherwise be emitted to the atmosphere. The carbon capture

308 efficiency is then defined as the quotient between the carbon in the gases exiting the fuel

309 reactor and the carbon in gases from both fuel and air reactors. Only $\mathrm{CH}_{4}, \mathrm{CO}$ and $\mathrm{CO}_{2}$ were

310 considered, as the amount of tars and hydrocarbons heavier than $\mathrm{CH}_{4}$ was proved to be

311 negligible.

$$
\eta_{C C}=\frac{\left[F_{C_{2}, F R}+F_{C O, F R}+F_{C_{4}, F R}\right]}{\left[F_{C O_{2}, F R}+F_{C O, F R}+F_{C H_{4}, F R}+F_{C O_{2}, A R}\right]}
$$


312 where $F_{i, F R}$ is the $i$ species molar flow in the fuel reactor inlet/outlet stream. $F_{C O_{2}, A R}$ is the

$313 \mathrm{CO}_{2}$ flow in the air reactor. Figure 2 shows the values of the carbon capture and char

314 conversion obtained at different fuel reactor temperatures. High carbon capture efficiencies

315 were expected due to the high volatile content of the lignite (Cuadrat et al., 2012). As it is

316 observed, the carbon capture efficiency increased with temperature from $82 \%$ at $875^{\circ} \mathrm{C}$ to

$31793 \%$ at $930^{\circ} \mathrm{C}$. Char conversion values were calculated and increased from $74.2 \%$ at $875^{\circ} \mathrm{C}$ to

$31889.3 \%$ at $930^{\circ} \mathrm{C}$ due to the increase in the char gasification rate with temperature.

3193.2 Fate of sulphur

320 Part of the sulphur contained in lignite is quickly released as gaseous compounds in the

321 pyrolysis taking place in the fuel reactor. The rest remains in the char generated and can be

322 released in the fuel reactor as char is gasified or in the air reactor as part of the ungasified

323 char reaches the air reactor.

$324 \quad$ 3.2.1 Sulphur distribution in fuel and air reactors

325 After measuring the different sulphur compounds present at the gaseous outlet of fuel and air 326 reactors, the sulphur distribution was determined. Figure 3 presents the weight percentage of

327 the sulphur measured which was released as gaseous compounds in the fuel and air reactors

328 at different fuel reactor temperatures. At any of the temperatures tested, more than $90 \%$ of the

329 sulphur in gases was released in the fuel reactor. This percentage increased with temperature

330 and the amount of sulphur released in the air reactor decreased in parallel. As it was already

331 shown before in Figure 2, char conversion is more favoured at high fuel reactor temperatures

332 and this leads to a lower amount of char reaching the air reactor. If less char is transported to

333 the air reactor, the sulphur contained in it and therefore released in the air reactor will

334 decrease with the fuel reactor temperature. 


\subsubsection{Sulphur compounds in fuel and air reactors}

338 Figure 4 shows the evolution of the sulphur gaseous species in the fuel reactor for different

339 fuel reactor temperatures. In the fuel reactor of an $i \mathrm{G}-\mathrm{CLC}$ system, $\mathrm{H}_{2} \mathrm{~S}, \mathrm{SO}_{2}, \mathrm{COS}$ and $\mathrm{CS}_{2}$

340 could be present in the outlet stream. The presence of COS might be favoured by the

341 presence of $\mathrm{CO}$ and $\mathrm{CO}_{2}$. However, only $\mathrm{H}_{2} \mathrm{~S}$ and $\mathrm{SO}_{2}$ were detected as main sulphur species

342 in the temperature interval $875-930^{\circ} \mathrm{C}$. No $\mathrm{COS}$ or $\mathrm{CS}_{2}$ were identified under the

343 experimental conditions used. The gaseous sulphur species liberated (mainly $\mathrm{H}_{2} \mathrm{~S}$ ) may react

344 with the oxygen carrier particles forming new more oxidized sulphur species. The molar ratio

345 between $\mathrm{H}_{2} \mathrm{~S}$ and $\mathrm{SO}_{2}$ depended on the fuel reactor temperature. As temperature increases,

346 the char conversion increases and the $\mathrm{H}_{2} \mathrm{~S} / \mathrm{SO}_{2}$ molar ratio slightly decreases from 0.33 to

347 0.23. At high temperatures, both volatile release and char gasification are favoured, as well as

348 the reaction of the gaseous products formed in these processes with the oxygen carrier

349 particles. The fact that the $\mathrm{H}_{2} \mathrm{~S} / \mathrm{SO}_{2}$ molar ratio decreases with the increase in temperature

350 can be explained by the enhancement in the conversion of $\mathrm{H}_{2} \mathrm{~S}$ from both volatiles and char

351 gasification to $\mathrm{SO}_{2}$ at high temperatures. This trend has been observed before for other

352 species reacting with oxygen, i.e. $\mathrm{H}_{2}, \mathrm{CO}$ and $\mathrm{CH}_{4}$.

354 In the air reactor, sulphur emissions are originated in the combustion of the unconverted char

355 reaching the air reactor. Therefore, the only sulphur species detected was $\mathrm{SO}_{2}$. The $\mathrm{SO}_{2}$

356 concentration measured at the outlet of the air reactor decreased from 65 to $20 \mathrm{ppm}$ as the

357 fuel reactor temperature increased. The enhancement of char conversion in the fuel reactor

358 reduced the amount of char transferred to the air reactor. The $\mathrm{SO}_{2}$ emission values reached

359 around $450 \mathrm{mg} / \mathrm{Nm}^{3}\left(6 \% \mathrm{O}_{2}\right)$ at $930^{\circ} \mathrm{C}$. This value is above the EU legal limit established for

360 power plants up to $300 \mathrm{MW}_{\text {th }}\left(200 \mathrm{mg} / \mathrm{Nm}^{3}, 6 \% \mathrm{O}_{2}\right)$. Lower $\mathrm{SO}_{2}$ emissions could be reached

361 if the fuel reactor temperature was increased. 


\subsubsection{Sulphur splitting}

363 Figure 5 presents the weight percentages corresponding to the sulphur released in the gaseous

364 streams from both fuel and air reactors. In average, the percentages of sulphur released as 365 gaseous compounds in both reactors oscillates around $75 \mathrm{wt} . \%$ of the total sulphur in the coal 366 fed. Therefore, there is approximately $25 \%$ of the sulphur in the coal fed which has not been 367 measured. Further investigations were conducted to determine the fate of this sulphur. There are several possibilities:

370 i. Sulphur retention by the ashes: It has been already reported that the $\mathrm{CaO}$ present in the 371 ashes of this lignite is capable of retaining sulphur during combustion by the formation of

$372 \mathrm{CaSO}_{4}$ (Adánez-Rubio et al., 2014). The ash content in this lignite is high (25.2\%) and the $373 \mathrm{CaO}$ content in the ashes is $6.5 \%$. Considering this, de Diego et al. (2013) calculated that the self-retention capacity of the lignite ashes would justify the retention of $10-15 \%$ of the sulphur fed with coal. This estimated percentage has been incorporated to Figure 5.

ii. Pyritic sulphur present in the lignite ashes: Lignite ashes contain pyritic sulphur. In the continuous unit, the combustion of this pyritic sulphur could take place once the char reaches the air reactor, as no oxygen is present in the gaseous atmosphere of the fuel reactor. However, the combustion rate of pyritic sulphur at the temperature conditions of the air reactor is low. The residence time of ash particles in the air reactor in the continuous unit would not be enough for the pyrite in coal ashes to be completely burned and the pyritic sulphur may escape unburned from the CLC system together with the fly ashes. It is worth noting that most ashes are not separated by the cyclone and are recovered in filters downstream the air reactor. To confirm this hypothesis, analyses were done to the fly ashes collected in the continuous unit and pyritic sulphur was found. In order to investigate the 
amount of pyritic sulphur in lignite, an experiment was conducted in a batch fluidized bed reactor. The methodology followed was described before in the experimental section. Figure 6 shows the concentration profiles of the main products $\left(\mathrm{CO}, \mathrm{CO}_{2}, \mathrm{SO}_{2}\right)$ all along the different processes (pyrolysis, gasification and oxidation) after being oxidized in the postcombustion chamber. The temperature selected for the experiment was $900^{\circ} \mathrm{C}$, as it is an intermediate value for the temperature interval used in this work. During the pyrolysis step, there is a maximum in $\mathrm{SO}_{2}(1300 \mathrm{ppm})$ and $\mathrm{CO}_{2}(2.5 \%)$ concentration when temperature approximately reaches $400^{\circ} \mathrm{C}$. Both maximum are associated with the volatile release from lignite. The amount of sulphur measured during this period corresponds to $22.1 \%$ of the sulphur fed with the coal introduced in the bed. In the steam gasification step, $46.8 \%$ of the initial sulphur was emitted. The molar $\mathrm{S} / \mathrm{C}$ ratio was calculated and it remained approximately constant during the steam gasification, close to a value of 0.03 . This fact indicates that both carbon and sulphur seem to be gasified simultaneously and at similar rate. Finally, $\mathrm{SO}_{2}$ release was observed during the period when air was introduced as fluidizing agent. The sulphur emitted during oxidation represented around $4.6 \%$ of initial sulphur. This value was considered as an indication of the amount of pyritic sulphur contained in lignite ashes, which were the only coal fraction present in the bed at that moment. Figure 5 included the percentage of pyritic sulphur determined through the experiment in the batch fluidized reactor. Further analyses about the origin of the inorganic sulphur in this lignite showed that no sulphides or sulphates were present. It is then speculated that the sulphur released during

407 steam gasification is mainly organic sulphur.

iii. Sulphur retention by the oxygen carrier: A thermodynamic study on the formation of iron-

410 sulphur solid species by reaction with the ilmenite was carried out considering the

411 experimental conditions in the continuous unit. The software HSC Chemistry 6.1 was used in 
412 the thermodynamical calculations ${ }^{4}$. According to this study, the formation of FeS in the fuel

413 reactor during ilmenite reduction is not favoured above stoichiometric conditions. Therefore,

414 no sulphur retention by the oxygen carrier is expected in these experiments. The

415 thermodynamic predictions were confirmed by the SEM-EDX analysis to used ilmenite

416 samples. The analysis on the surface of the particles did not evidence the presence of sulphur,

417 therefore it was assumed that all the sulphur in coal was either released in the volatiles or

418 retained in the lignite char or ash. An activation of ilmenite after the combustion of fuels with

419 high sulphur content has been reported in the literature (Moldenhauer et al., 2013). Therefore,

420 the ilmenite particles were analyzed after 55 hours of continuous hot fluidization to check any

421 change that may occur in their reactivity and no differences were found with respect to the

422 sample before use. Besides, it is known that the transport capacity of ilmenite $\left(R_{O C}\right)$ may

423 decrease with the number of redox cycles, as a consequence of the migration of $\mathrm{Fe}_{2} \mathrm{O}_{3}$ to the

424 external part of the particle when ilmenite was highly reduced (Adánez et al., 2010). The

425 transport capacity of the calcined and used ilmenite was determined in experiments in a TGA

426 at $950^{\circ} \mathrm{C}$ using as reducing mixture $5 \% \mathrm{H}_{2}+40 \% \mathrm{H}_{2} \mathrm{O}$, so that the final reduced form was

$427 \mathrm{Fe}_{3} \mathrm{O}_{4}$. In this case, no changes were detected after operation and the oxygen transport

428 capacity remained $4.3 \%$ what agrees with results previously reported (Cuadrat et al., 2011).

430 Once all the possible non-measured contributions to the sulphur balance were included in

431 Figure 5, the sulphur balance closed around 95\% on average, which can be considered as

432 good result. Possible $\mathrm{SO}_{3}$ emission in the air reactor was not measured, although it is believed

433 that formation of $\mathrm{SO}_{3}$ in the air reactor would have minor importance regarding the sulphur

434 balance to the whole CLC unit. It has been reported that only fractions below $4 \%$ of the total

\footnotetext{
${ }^{4}$ HSC Chemistry 6.1, Chemical reaction and equilibrium software with thermochemical database and simulation module, Oututec Research Oy, Pori, Finland; 2008.
} 
435 sulphur present as $\mathrm{SO}_{2}$ can be converted to $\mathrm{SO}_{3}$ in combustion processes (Spörl at al., 2013).

436 According to this, the formation of $\mathrm{SO}_{3}$ could represent $0.3 \%$ of the total sulphur fed.

\subsection{Fate of nitrogen}

438 The presence of $\mathrm{N}_{2}$ in the combustion atmosphere at high temperatures favours the formation 439 of $\mathrm{NO}_{\mathrm{x}}$ (thermal $\mathrm{NO}_{\mathrm{x}}$ ) as it has been observed in conventional combustion. However, this 440 contribution to $\mathrm{NO}_{\mathrm{x}}$ formation is not present in CLC, as no $\mathrm{N}_{2}$ enters in the fuel reactor gases.

441 Therefore only the nitrogen in the fuel can be present in the fuel reactor, either $\mathrm{N}_{2}$ or $\mathrm{NO}_{\mathrm{x}}$. In order to avoid $\mathrm{N}_{2}$ in the gases fed to the system $\mathrm{CO}_{2}$ was used to fluidize the loop seal and in

443 the screw feeder.

444 The nitrogen present in the lignite may be released during devolatilization as $\mathrm{NH}_{3}$ or $\mathrm{HCN}$.

445 Depending on the combustion conditions, these nitrogenated species can evolve to $\mathrm{N}_{2}$ or $446 \mathrm{NO}_{\mathrm{x}}$. In the case of molecular nitrogen, it could be formed both from homogeneous reactions 447 in the gas phase or due to NO reduction by the char particles present in the fuel reactor. As it 448 was done with sulphur emissions, the presence of the abovementioned species was analyzed 449 both in the fuel and air reactors. In this case, data were only available at 875 and $930^{\circ} \mathrm{C}$. Most 450 of the nitrogen in coal was found in the fuel reactor outlet and this partition does not seem to 451 be notably affected by temperature. Different nitrogen compounds were detected and are 452 detailed next.

\section{$453 \quad$ 3.3.1 Nitrogen in fuel and air reactors}

454 Figure 7 (A) shows the splitting of the nitrogen contained in the lignite fed in the experiments 455 at 875 and $930^{\circ} \mathrm{C}$, respectively. In both experiments most of the nitrogen fed was detected in 456 the gaseous phase in fuel and air reactors. On average, it can be said that $92 \%$ of the nitrogen 457 in lignite was measured, which can be considered as a good closure for the nitrogen balance.

458 At the fuel reactor outlet, only traces of $\mathrm{NH}_{3}$ and $\mathrm{HCN}$ were identified using the mass

459 spectrometer, but in such a low amount that could not be quantified. It seems that the $\mathrm{NH}_{3}$ 
and $\mathrm{HCN}$ generated in lignite devolatilization were oxidized by the oxygen carrier particles at the temperatures tested. This is in line with the results reported by Song et al. (Song et al., 2012, 2013), who after a thermodynamic study assuming fuel reactor temperatures between $600-1000^{\circ} \mathrm{C}$, concluded that both species could be oxidized by $\mathrm{Fe}_{2} \mathrm{O}_{3}$ yielding NO. Then, NO can evolve or not to $\mathrm{N}_{2}$, following homogeneous (gas phase) and heterogeneous reactions.

The only $\mathrm{NO}_{\mathrm{x}}$ detected and quantified was $\mathrm{NO}$. The analyses showed that $\mathrm{N}_{2} \mathrm{O}$ was not formed during these processes and only traces of $\mathrm{NO}_{2}$ were identified by the mass spectrometer. The major nitrogenated species observed in the fuel reactor was $\mathrm{N}_{2}(0.21-0.24$ vol. \%). According to these results, around $99 \%$ of the nitrogen measured in the fuel reactor was in the form of $\mathrm{N}_{2}$.

In the air reactor the nitrogen contained in the unconverted char was released as NO. No trace of $\mathrm{N}_{2} \mathrm{O}$ or $\mathrm{NO}_{2}$ was detected. Figure 7 (B) presents the results obtained in the air reactor with more detail. The amount of NO present in the outlet stream depended on the fuel reactor temperature and is correlated with the evolution of the carbon flow reaching the air reactor. The lower the amount of char being burned there, the lower the level of NO emissions. At the highest temperature tested $\left(930^{\circ} \mathrm{C}\right)$, the value of $\mathrm{NO}$ emissions was $74 \mathrm{mg} / \mathrm{Nm}^{3}\left(6 \% \mathrm{O}_{2}\right)$,

477 lower than the $200 \mathrm{mg} / \mathrm{Nm}^{3}\left(6 \% \mathrm{O}_{2}\right)$ limit set by EU legislation.

\subsection{Fate of mercury}

479 Mercury measurements at the outlet of both fuel and air reactors were performed in order to 480 analyze the fate of mercury when lignite was used as fuel. During the analyses, the temperature in the fuel reactor was $910^{\circ} \mathrm{C}$. The mercury present in the fines at the outlet of

482 the air reactor was determined. These solids were mainly coal ash and no mercury was found 483 during the analysis. The initial mercury content of lignite was $0.10 \mathrm{mg} \mathrm{Hg} / \mathrm{kg}$. Around $31.5 \%$ 484 of this amount was released in the fuel reactor while $67.7 \%$ was liberated in the air reactor. In 
conventional combustion, most of the mercury in coal is vaporized once coal is fed into the combustion chamber. However, a significant amount of mercury remained in the char after devolatilization in the CLC experiments. This char was transferred to the air reactor where it was burned and the rest of the mercury released. The reason for this important difference with combustion processes may lay in the different atmospheres present in a boiler and in the fuel reactor of a CLC system. In this case, char is gasified in the fuel reactor, although gasification products are oxidized in situ by the oxygen carrier. It has been previously observed that in coal gasification environments, where steam is present in high proportion, mercury release was suppressed (Sekine et al., 2008). This mercury partition between fuel and air reactors corresponds to total mercury emissions of 15.5 and $2.1 \mu \mathrm{g} / \mathrm{Nm}^{3}$, respectively. Both values are expressed in dry basis. Although there is no legislation already available for Europe, the mercury concentration in the air reactor is quite low. As a guideline, the mercury emission limit from incineration systems is indicated. According to Directive 2010/75/UE, the maximum mercury emission in these installations is set to $0.05 \mathrm{mg} / \mathrm{Nm}^{3}$. The concentration value found for the air reactor was 25 times lower. The speciation of mercury was also

500 determined for each of the reactors. In the fuel reactor, the ratio $\mathrm{Hg}^{0} / \mathrm{Hg}^{\text {total }}$ was 0.75 and in the air reactor it was 0.46 . These results indicate that the major species in the fuel reactor was $\mathrm{Hg}^{0}$. In the air reactor, the amount of $\mathrm{Hg}^{2+}$ was slightly higher than that corresponding to $\mathrm{Hg}^{0}$.

503 Further analysis would be required to understand the reasons for the speciation in both 504 reactors and will be the subject of ongoing investigation in our research group.

\section{Assessment on pollutant emissions and $\mathrm{CO}_{2}$ quality}

507 As in any other power generation unit, the emissions to the atmosphere in the air reactor

508 should be under the limits imposed by legislation for different pollutants. Legislation for combustion systems has been set for both $\mathrm{SO}_{2}$ and $\mathrm{NO}_{\mathrm{x}}$, although in our experiments $\mathrm{SO}_{2}$ was 
the only pollutant with a concentration at the outlet of the air reactor exceeding that allowed

$511\left(200 \mathrm{mg} / \mathrm{Nm}^{3}, 6 \% \mathrm{O}_{2}\right)$. Therefore, this analysis will focus on these pollutants. All the sulphur

512 and nitrogen emissions in the air reactor originate from the char transported from the fuel

513 reactor. Therefore, an interesting measure to be taken in order to reduce the emissions from

514 the air reactor would be to improve char conversion in the fuel reactor, so that less char is

515 burned in the air reactor. This can be done by means of a carbon separation unit located

516 between fuel and air reactors. The effect of the efficiency of the carbon separation unit ( $\left.\eta_{C S S}\right)$

517 on carbon capture has been described before (Mendiara et al., 2013). This time the effect of

518 its incorporation on pollutant emissions in the air reactor will be investigated. For that

519 purpose, a simple model based on carbon balances to the fuel reactor and carbon separation

520 unit was used to estimate the emission levels reached for different efficiencies of the carbon

521 separation unit (Mendiara et al., 2013). The model considers the char gasification rate at the

522 corresponding temperatures and using that value, first the char conversion and then the

523 carbon capture efficiency are calculated for different $\eta_{C S S}$ values. Once the char conversion is

524 known, the estimation of the emissions in the air reactor can be done with the ultimate

525 analysis of lignite char.

526

527 Figure 8 presents the results obtained using this model for lignite and ilmenite at a

528 temperature in the fuel reactor of $930^{\circ} \mathrm{C}$. First of all, it can be seen that the incorporation of a

529 carbon separation unit increased the char conversion and carbon capture efficiency which was

530 already high for lignite. The efficiency of the carbon separation unit has been reported to be

5310.98 during operation in a $100 \mathrm{~kW}_{\text {th }}$ CLC unit (Abad et al., 2013). As a consequence, less

532 char is reaching the air reactor in those conditions. Therefore, the concentration values of $\mathrm{SO}_{2}$

533 and NO in the air reactor decreased when the efficiency of the carbon separation unit was

534 higher. If $\eta_{C S S}=0.98$ is considered, then the emission values in the air reactor can be estimated 
535

536

537

538

539

540 Following the results presented above regarding the composition of the gaseous stream at the

as $9.8 \mathrm{mg} / \mathrm{Nm}^{3} \mathrm{SO}_{2}$ and $1.0 \mathrm{mg} / \mathrm{Nm}^{3} \mathrm{NO}$ (both at $6 \% \mathrm{O}_{2}$ excess). These $\mathrm{SO}_{2}$ and $\mathrm{NO}$ emissions are well below the legal limits. Therefore, considering the estimation of emissions presented, it can be said that, with the incorporation of a carbon separation unit in the CLC system no problems with $\mathrm{SO}_{2}$ emissions in the air reactor may be expected. outlet of the fuel reactor, some considerations about $\mathrm{CO}_{2}$ quality can be elaborated. Different compounds have been found in the $\mathrm{CO}_{2}$ stream $\left(\mathrm{CO}, \mathrm{H}_{2}, \mathrm{CH}_{4}, \mathrm{H}_{2} \mathrm{~S}, \mathrm{SO}_{2}, \mathrm{~N}_{2}, \mathrm{NO}_{\mathrm{x}}\right.$ and $\left.\mathrm{Hg}^{0} / \mathrm{Hg}^{2+}\right)$. The values of these compounds in the experiment at the highest temperature $\left(930^{\circ} \mathrm{C}\right.$ ) have been included in Table 1 (dry $\mathrm{N}_{2}$ free basis) in order to compare with the recommendations given by de Visser et al. (2008) for $\mathrm{CO}_{2}$ quality. The conclusions obtained in the comparison are qualitatively the same as in the case that a carbon separation unit would be used. As it can be observed, the amounts of $\mathrm{CH}_{4}, \mathrm{~N}_{2}, \mathrm{H}_{2}$ and $\mathrm{NO}_{\mathrm{x}}$ are under the specification limits. However, there are an excess of unburned $\mathrm{CO}$ and sulphur compounds at the fuel reactor outlet compared to the recommended values. The $\mathrm{CO}$ concentration is more than 20 times that allowed and the $\mathrm{CO}_{2}$ concentration does not reach the required $95.5 \%$. The values of $\mathrm{H}_{2} \mathrm{~S}$ and $\mathrm{SO}_{2}$ are more than 10 and 100 times those specified, respectively. In the case of mercury no limits where suggested. Therefore, the $\mathrm{CO}_{2}$ stream leaving the fuel reactor should be subjected to several treatments in order to adequate the content of these compounds to the values needed for safe transport and storage.

First of all, unconverted gases (especially CO) should be burned. Different alternatives have been recently proposed to increase the combustion efficiency in CLC of solid fuels. Among them, the highest reduction in the unconverted gases emitted was reached using a secondary fuel reactor at the fuel reactor outlet (Gayán et al., 2013). The next step would be the removal of the sulphur compounds. Absorption processes to selectively remove $\mathrm{H}_{2} \mathrm{~S}$ from process 
streams containing carbon dioxide are based on methyldiethanolamine (MDEA). The reaction rate of MDEA with $\mathrm{CO}_{2}$ is lower than with $\mathrm{H}_{2} \mathrm{~S}$ therefore no much $\mathrm{CO}_{2}$ is absorbed by this amine (Rogers et al., 1998). The removal of $\mathrm{SO}_{2}$ can be carried out using the same technology as in air-fired combustion. One of the most widely used is the wet flue gas desulfurization (FGD). In this process, $\mathrm{SO}_{2}$ is removed using limestone slurry. The performance of this technology has been already tested with flue gases from oxyfuel combustion (Hansen et al., 2011). It is interesting to remind that $\mathrm{Hg}^{2+}$ could be eliminated in the FGD unit (Stergaršek et al., 2008). Elemental mercury could be adsorbed using the activated carbon injection (ACI) technology (Pavlish et al., 2003). Finally, the $\mathrm{CO}_{2}$ stream should be dried and then compressed.

\section{Conclusions}

The fate of sulphur, nitrogen and mercury was evaluated at different fuel reactor temperatures in the combustion of lignite in a continuous $i \mathrm{G}-\mathrm{CLC}$ unit using ilmenite as oxygen carrier. High carbon capture efficiencies were obtained in the $875-930^{\circ} \mathrm{C}$ temperature interval. The sulphur, nitrogen and mercury emissions in both fuel and air reactors were analyzed.

Regarding sulphur emissions, more than $90 \%$ of the sulphur in coal was released in the fuel reactor as $\mathrm{H}_{2} \mathrm{~S}$ or $\mathrm{SO}_{2}$. The presence of COS or $\mathrm{CS}_{2}$ was not detected. The molar $\mathrm{H}_{2} \mathrm{~S} / \mathrm{SO}_{2}$ ratio slightly decreased with the fuel reactor temperature, indicating that $\mathrm{H}_{2} \mathrm{~S}$ consumption maybe favoured by temperature. In the air reactor, sulphur was released as $\mathrm{SO}_{2}$ and the emission level was related to the amount of unconverted char being burned in the air reactor. The incorporation of a carbon separation unit in the $i \mathrm{G}-\mathrm{CLC}$ system allowed to comply with

584 the legal emission limits for $\mathrm{SO}_{2}$ in the air reactor. Regarding the fate of nitrogen in coal, $\mathrm{N}_{2}$ 
was the main compound in the fuel reactor. It represented around $99 \%$ of the nitrogen

586 measured in the fuel reactor. In the air reactor, the nitrogen released by the unconverted char

587 was emitted as NO at a lower level than the legislation limit. A third of the mercury fed with

588 coal was released in the fuel reactor mainly as $\mathrm{Hg}^{0}$, whereas in the air reactor higher amounts

589 of $\mathrm{Hg}^{2+}$ were found. In order to ensure adequate quality of the $\mathrm{CO}_{2}$ stream produced in the

590 fuel reactor, conversion of unburned gases and $\mathrm{H}_{2} \mathrm{~S} / \mathrm{SO}_{2}$ removal should be addressed.

591

\section{Acknowledgments}

593 The authors thank the Government of Aragón and La Caixa (2012-GA-LC-076 project) and

594 the Spanish Ministry for Science and Innovation (ENE2010-19550 project) for the financial

595 support. T. Mendiara thanks for the "Juan de la Cierva" post-doctoral contract awarded by

596 this Ministry. This work was also partially supported by the European Commission, under the

597 RFCS program (ACCLAIM Project, Contract RFCP-CT-2012-40 
Abad, A., Adánez, J., de Diego, L.F., Gayán, P., García-Labiano, F., Lyngfelt, A. 2013. Fuel reactor model validation: Assesment of the key parameters affecting the chemical-looping combustion of coal. Int. J. Greenh. Gas Con. 19, 541-551.

602

603

Adánez, J., Cuadrat, A., Abad, A., Gayán, P., de Diego, L.F., García-Labiano, F., 2010.

604

Ilmenite activation during consecutive redox cycles in Chemical-Looping Combustion. Energ 605 Fuel 24, 1402-1413.

606

607

Adánez, J., Abad, A., García-Labiano, F., Gayán, P., de Diego, L.F., 2012. Progress in

608

Chemical-Looping Combustion and Reforming Technologies. A review, Prog. Energ.

609

Combust. 38, 215-282.

610

611 Adánez-Rubio, I., Abad, A., Gayán, P., García-Labiano, F., de Diego, L.F., Adánez, J., 2014.

612 The fate of sulphur in the Cu-based Chemical Looping with Oxygen Uncoupling (CLOU)

613 Process. Appl .Energ. 113, 1855-1862.

614

Anheden, M., Andersson, A., Bernstone, C., Eriksson, S., Yan, J., Liljemark, S., Wall, C., 616 2004. $\mathrm{CO}_{2}$ quality requirement for a system with $\mathrm{CO}_{2}$ capture, transport and storage. In:

617 GHGT-7 (Greenhouse Gas Control Technologies- $7^{\text {th }}$ International Conference), Vancouver, 618 September 5-9, 2004.

619

620 Attar, A., 1978. Chemistry, thermodynamics and kinetics of reactions of sulphur in coal-gas 621 reactions: a review. Fuel 57, 201-212.

622 
623 Berguerand, N., Lyngfelt, A., 2008. The use of petroleum coke as fuel in a $10 \mathrm{kWth}$

624 chemical-looping combustor. Int. J. Greenh. Gas Con. 2, 169-179.

625

626 Bidwe, A.R., Mayer, F., Hawthorne, C., Charitos, A., Schuster, A., Scheffknecht, G., 2011.

627 Use of ilmenite as an oxygen carrier in Chemical-Looping Combustion - Batch and

628 continuous dual fluidized bed investigation. Energy Procedia, 4, 433-440.

629

630 Cao, Y., Pan, W. P., 2006. Investigation of chemical looping combustion by solid fuels. 1.

631 Process analysis, Energ. Fuel 20, 1836-1844.

632

633 Cabello, A., Dueso, C., García-Labiano, F., Gayán, P., Abad, A., de Diego, L.F., Adánez, J., 634 2013. Performance of a highly reactive impregnated $\mathrm{Fe}_{2} \mathrm{O}_{3} / \mathrm{Al}_{2} \mathrm{O}_{3}$ oxygen carrier with $\mathrm{CH}_{4}$ 635 and $\mathrm{H}_{2} \mathrm{~S}$ in a $500 \mathrm{~W}_{\text {th }}$ CLC unit. Fuel. Submitted for publication.

636

637 Cuadrat, A., Abad, A., García-Labiano, F., Gayán, P., de Diego, L.F., Adánez, J., 2011. The 638 use of ilmenite as oxygen carrier in a $500 \mathrm{~W}_{\text {th }}$ Chemical-Looping Coal Combustion unit. Int. 639 J. Greenh. Gas Con. 5, 1630-1642.

640

641 Cuadrat, A., Abad, A., García-Labiano, F., Gayán, P., de Diego, L.F., Adánez, J., 2012.

642 Relevance of the coal rank on the performance of the in situ gasification chemical-looping 643 combustion. Chem. Eng. J. 195-196, 91-102.

644

645 Dennis, J.S., Scott, S.A, Hayhurst, A.N., 2006. In situ gasification of coal using steam with 646 chemical looping: a technique for isolating $\mathrm{CO}_{2}$ from burning a solid fuel. J. Energy Inst. 79, $647 \quad 187-190$. 
648

649

650

651

652

653

654

655

656

657

658

659

660

661

662

663

664

665

666

667

668

669

670

671

672

de Diego, L.F., Rufas, A., García-Labiano, F., de las Obras-Loscertales, M., Abad, A., Gayán, P., et al., 2013. Optimum temperature for sulphur retention in fluidised beds working under oxy-fuel combustion conditions. Fuel 114, 106-113.

de Visser, E., Hendriks, C., Barrio, M., Mølnvik, M., de Koeijer, G., Liljemark, S., Le Gallo, Y., 2008. Dynamis $\mathrm{CO}_{2}$ quality recommendations. Int. J. Greenh. Gas Con. 2, 478-484.

Dueso, C., Izquierdo, M.T., García-Labiano, F., de Diego, L.F., Abad, A., Gayán, P., Adánez, J., 2012. Effect of $\mathrm{H}_{2} \mathrm{~S}$ on the behaviour of an impregnated NiO-based oxygen-carrier for chemical-looping combustion (CLC). Appl Catal B 126, 186-199.

EASAC policy report 20. Carbon capture and storage in Europe. German National Academy of Sciences Leopoldina, DVZ-Daten-Service GmbH, Halle/Saale, Germany, 2013. ISBN: 978-3-8047-3180-6

Eide, L.I., Anheden, M., Lyngfelt, A., Abanades, C., Younes, M., Clodic, D. et al., 2005. Novel capture processes, Oil Gas Sci. Technol. 60, 497-508.

Forero, C.R., Gayán, P., García-Labiano, F., de Diego, L.F., Abad, A., Adánez, J. 2010. Effect of gas composition in Chemical-Looping Combustion with copper-based oxygen carriers: Fate of sulphur, Int. J. Greenh. Gas Con. 4, 762-770.

Gayán, P., Abad, A., de Diego, L.F., García-Labiano, F., Adánez, J., 2013. Assessment of technological solutions for improving Chemical Looping Combustion of solid fuels with $\mathrm{CO}_{2}$ capture. Chem. Eng. J. 233, 56-69. 
673 Galbreath, K.C., Zygarlicke, C.J., 1996. Mercury speciation in coal combustion and

674 gasification flue gases, Environ. Sci. Technol. 30, 2421-2426.

675

676 Glarborg, P., Jensen, A.D. Johnsson, J.E., 2003. Fuel nitrogen conversion in solid fuel fired 677 systems, Prog. Energ. Combust. 29, 89-113.

678

679

IPCC, 2005. IPCC Special Report on Carbon Dioxide Capture and Storage. Cambridge

680

University Press, Cambridge, United Kingdom and New York, NY, USA.

681

682 Hansen, B.B., Fogh, F., Knudsen, N.O., Kiil, S., 2011. Performance of a wet flue gas

683 desulfurization pilot plant under oxy-fuel conditions. Ind. Eng. Chem. Res. 50, 4238-4244.

684

685

IPCC, 2007. Summary for Policymakers, in: Solomon, S., Qin, D., Manning, M., Chen, Z., 686 Marquis, M., Averyt, K.B., Tignor, M., Miller, H.L. (Eds.), Climate Change 2007: The

687

Physical Science Basis. Contribution of Working Group I to the Fourth Assessment Report of 688 the Intergovernmental Panel on Climate Change, Cambridge University Press, Cambridge, 689 United Kingdom and New York, NY, USA.

690

691 Leion, H., Mattisson, T., Lyngfelt, A., 2007. The use of petroleum coke as fuel in chemical692 looping combustion. Fuel 86, 1947-1958.

693

694 Mattisson, T., Lyngfelt, A., Leion, H., 2009. Chemical-looping with oxygen uncoupling for 695 combustion of solid fuels. Int. J. Greenh. Gas Con. 3, 11-19.

696 
Moldenhauer, P., Rydén, M., Mattisson, T., Younes, M., Lyngfelt, A., 2014. The use of

ilmenite as oxygen carrier with kerosene in a $300 \mathrm{~W}$ CLC laboratory reactor with continuous circulation. App. Energ. 113, 1846-1854.

704

Pavlish, J.H., Sondreal, E.A., Mann, M.D., Olson, E.S., Galbreath, K.C., Laudal, D.L., et al., 2003. Status review of mercury control options for coal-fired power plants. Fuel Process. Technol. 82, 89-165.

708

Olson, E.S., Mibeck, B.A., 2005. Oxidation kinetics and the model for mercury capture on carbon in flue gas. In: International Conference on Air Quality V, Arlington, VA.

Rogers, W.J., Bullin, J.A., Davison, R.R. 1998. FTIR measurements of acid-gasmethylethanolamine systems, AIChE J. 44, 2423-2430.

714

Schwebel, G.L., Leion, H., Krumm, W., 2012. Comparison of natural ilmenite as oxygen carriers in chemical-looping combustion and influence of water gas shift reaction on gas composition, Chem. Eng. Res. Design 90, 1351-1360.

719 Sekine, Y., Sakajiri, K., Kikuchi, E., Matsukata, M., 2008. Release behavior of trace elements

720 from coal during high-temperature processing, Powder Technol. 180, 210-215. 
L. Shen, J. Wu, Z. Gao, J. Xiao, Characterization of chemical looping combustion of coal in a $1 \mathrm{~kW}_{\text {th }}$ reactor with a nickel-based oxygen carrier, Combust Flame 157 (2010) 934-942.

724

725 Song, T., Shen, L., Xiao, J., Chen, D., Gu, H., Zhang, S., 2012. Nitrogen transfer of fuel-N in 726 chemical looping combustion, Combust Flame 159 (2012) 1286-1295.

727

728

Song, T., Shen, T., Shen, L., Xiao, J., Gu, H., Zhang, H.S., 2013. Evaluation of hematite

729 oxygen carrier in chemical-looping combustion of coal. Fuel 104, 244-252.

730

731 Spörl, R., Belo, L., Shah, K., Stanger, R., Maier, J., Wall, T., Scheffknecht, G. 2013. SO

732 emission behaviour in coal-fired oxy-fuel combustion simulating different extents of recycle

733 gas cleaning. $3^{\text {rd }}$ Oxyfuel Combustion Meeting, Ponferrada, Spain $9^{\text {th }}-13^{\text {th }}$ September 2013. 734

735 Stergaršek, A., Horvat, M., Kotnik, J., Tratnik, J., Frkal, P., Kocman, D. et al., 2008. The role 736 of flue gas desulphurisation in mercury speciation and distribution in a lignite burning power 737 plant. Fuel 87, 3504-3512. 


\section{Nomenclature}

$739 F_{\mathrm{CO}_{2}, A R}:$ carbon dioxide molar flow in the air reactor $(\mathrm{mol} / \mathrm{s})$

$740 \quad F_{i, F R}: i$ species molar flow in the fuel reactor inlet/outlet stream (mol/s)

$741 F_{C, v o l}$ : carbon flow from the volatile matter $(\mathrm{mol} / \mathrm{s})$

$742 \quad M_{\mathrm{O}_{2}}$ : molar mass of molecular oxygen $(0.032 \mathrm{~kg} / \mathrm{mol})$

$743 \quad \dot{m}_{O C}$ : mass-based solid circulation rate $(\mathrm{kg} / \mathrm{s})$

$744 \quad \dot{m}_{S F}$ : coal feeding rate $(\mathrm{kg} / \mathrm{s})$

$745 R_{O C}$ : oxygen transport capacity

$746 \quad X_{\text {char }}$ : char conversion

747

748 Greek symbols

$749 \phi$ : oxygen carrier to fuel ratio

$750 \Omega_{S F}:$ coal oxygen demand ( $\mathrm{kg}$ oxygen $/ \mathrm{kg}$ coal)

$751 \Omega_{T}$ : total oxygen demand

$752 \eta_{C C}:$ carbon capture efficiency

$753 \eta_{\text {CSS }}$ : carbon separation efficiency in the carbon separation unit 
Figure 1. Experimental unit ICB-CSIC-s1

756

Figure 2. Carbon capture efficiency $\left(\eta_{C C}\right)$, char conversion $\left(X_{\text {char }}\right)$ and total oxygen demand $\left(\Omega_{T}\right)$ at different temperatures in the fuel reactor

Figure 3. Sulphur emission distribution (wt \%) in the gaseous streams from fuel and air reactors for different fuel reactor temperatures

Figure 4. Concentration (dry basis) of sulphur compounds at FR outlet for different fuel

761 reactor temperatures

762

Figure 5. Sulphur splitting in experiments with ilmenite and lignite: $\mathbf{F R}_{\mathbf{g}}$ (fuel reactor gas outlet) $\mathbf{A R}_{\mathbf{g}}$ (air reactor gas outlet) Pyr (pyritic sulphur in ashes) Ash (self-retention by ashes)

Figure 6. Evolution with time of the main products from lignite pyrolysis and steam gasification at $900^{\circ} \mathrm{C}$

Figure 7. (A) Nitrogen splitting in experiments with ilmenite and lignite: N_FR (fuel reactor gas outlet) N_AR (air reactor gas outlet) (B) carbon molar flow and NO emissions in the air reactor at different fuel reactor temperatures

Figure 8. $\mathrm{SO}_{2}$ and $\mathrm{NO}$ emissions together with carbon capture efficiency and char conversion for different efficiencies in the carbon separation unit in experiments with ilmenite and lignite at $930^{\circ} \mathrm{C}$ 


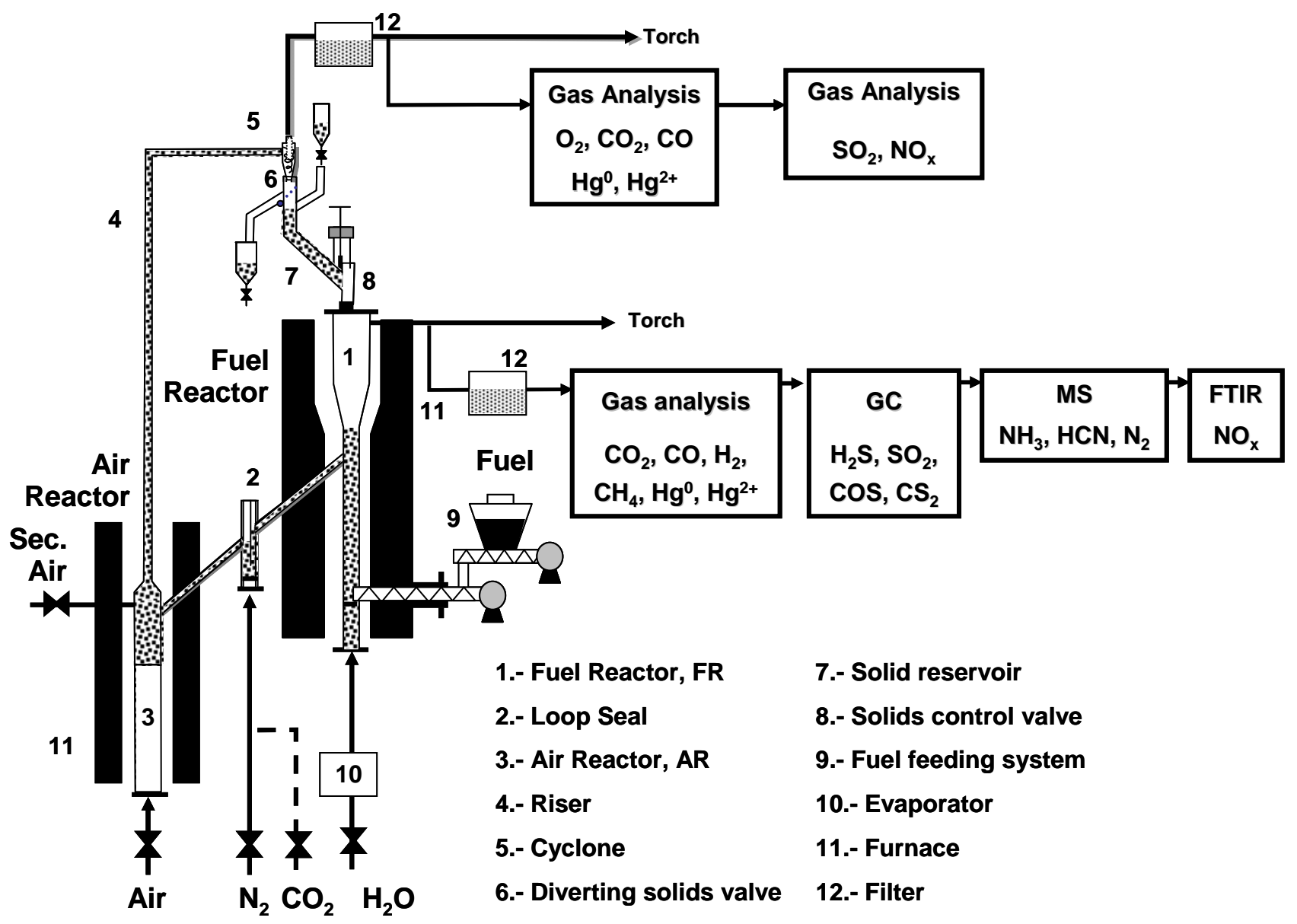

791

792

Figure 1. Experimental unit ICB-CSIC-s1

793

794

795

796

797

798

799 


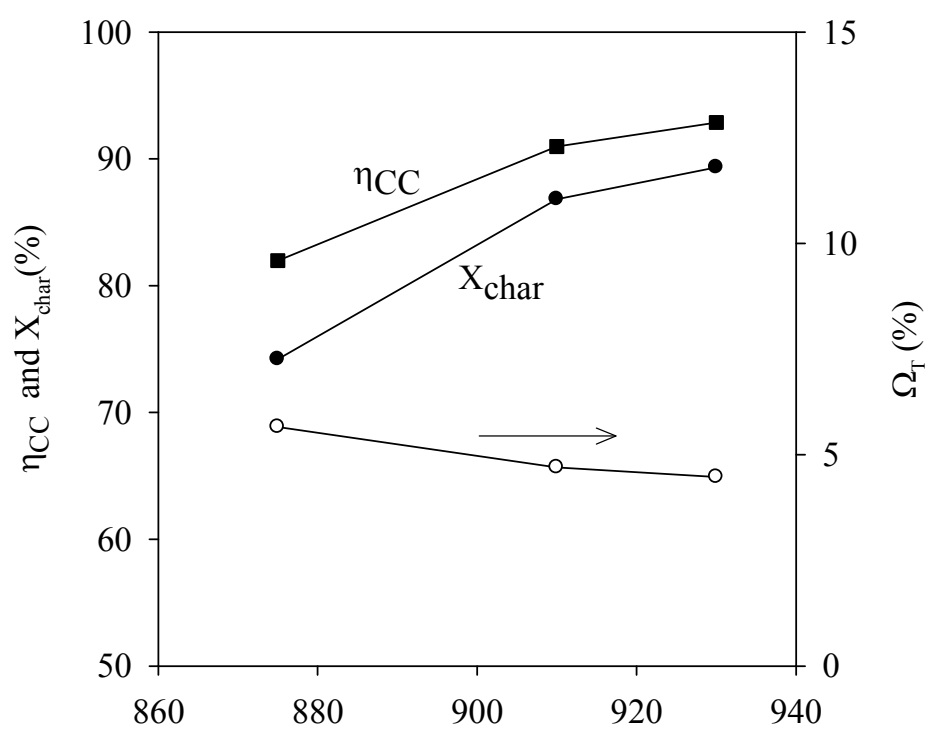

800

Temperature FR $\left({ }^{\circ} \mathrm{C}\right)$

801 Figure 2. Carbon capture efficiency $\left(\eta_{C C}\right)$, char conversion $\left(X_{c h a r}\right)$ and total oxygen demand

$802\left(\Omega_{T}\right)$ at different temperatures in the fuel reactor

803

804

805

806

807

808

809

810

811

812

813

814

815

816

817 


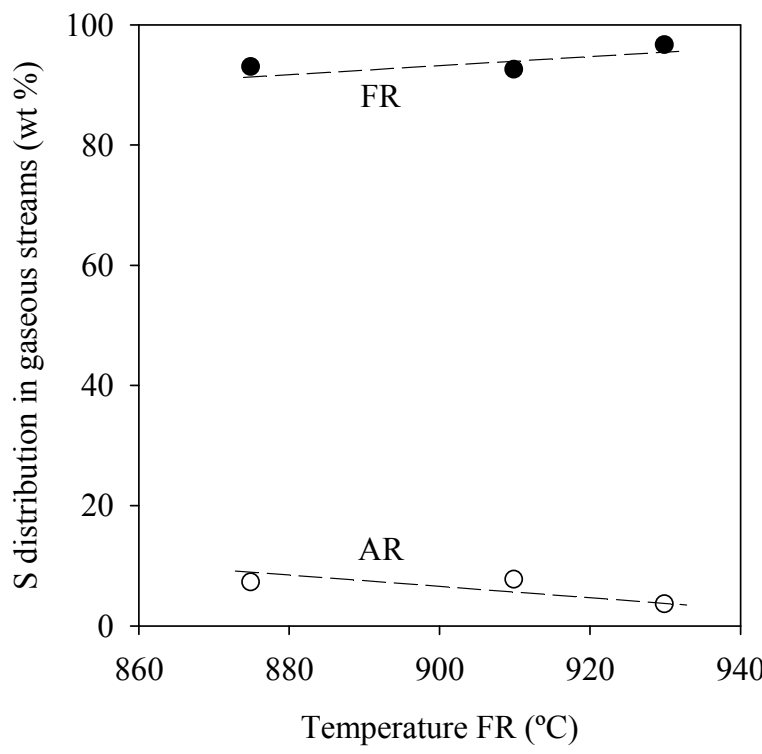

818

Figure 3. Sulphur emission distribution (wt \%) in the gaseous streams from fuel and air

820 reactors for different fuel reactor temperatures

821

822

823

824

825

826

827

828

829

830

831 


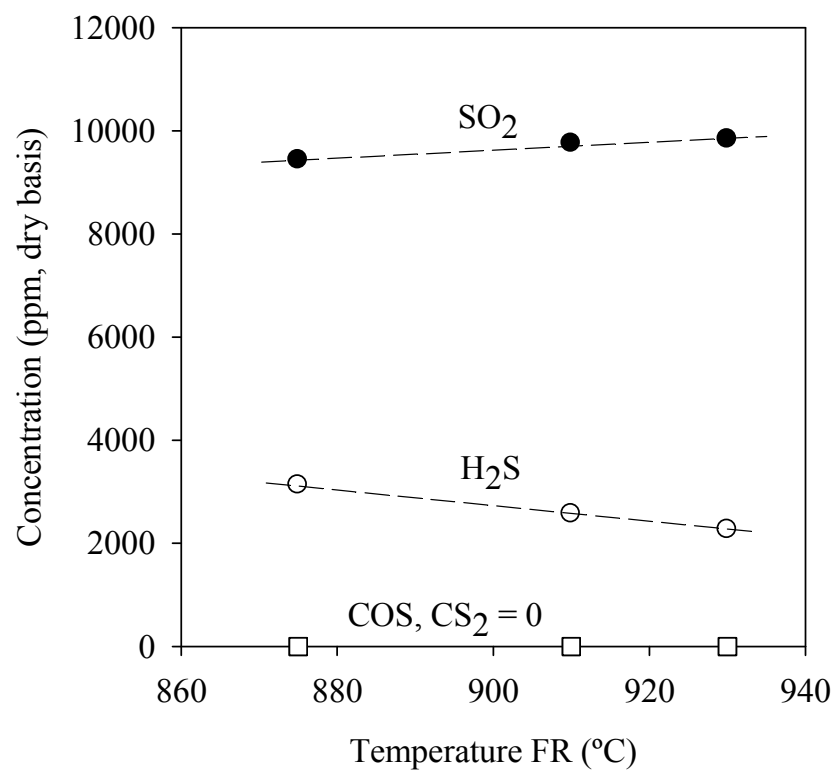

833 Figure 4. Concentration (dry basis) of sulphur compounds at FR outlet for different fuel

834 reactor temperatures

835

836

837

838

839

840

841

842

843

844

845

846

847

848

849 


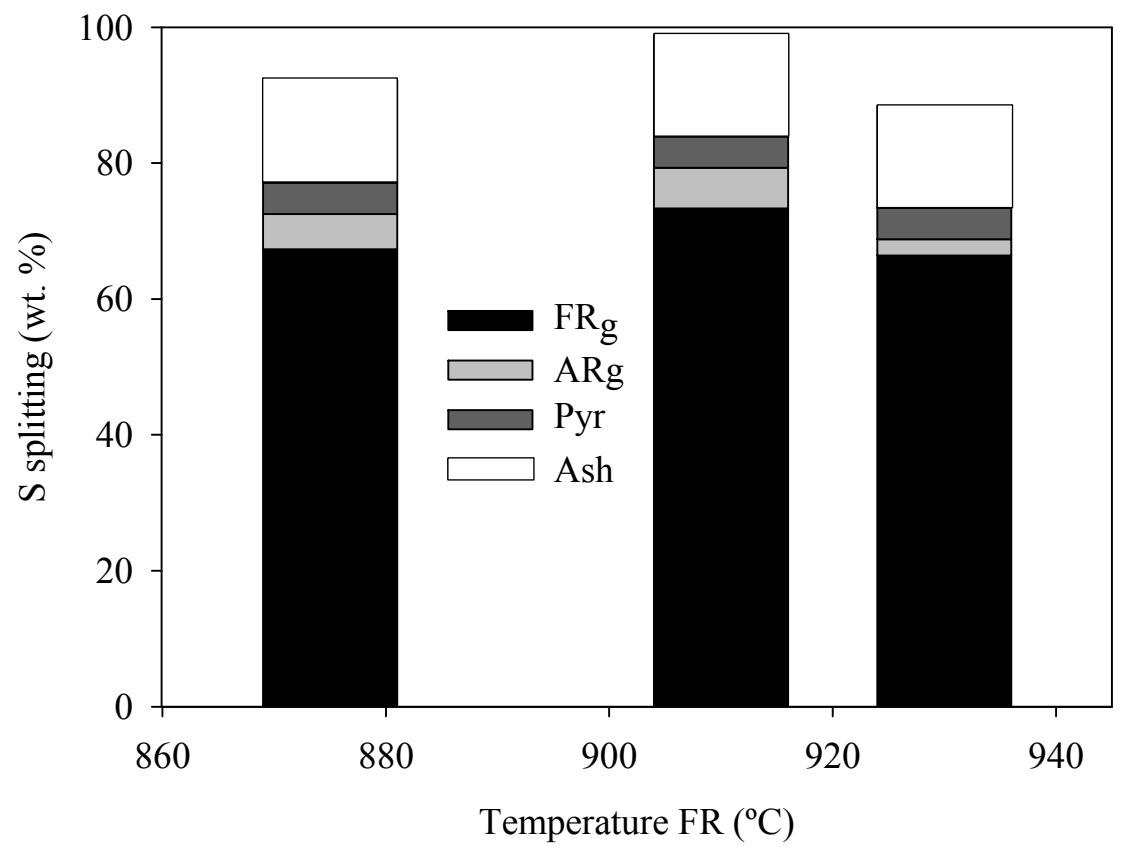

851 Figure 5. Sulphur splitting in experiments with ilmenite and lignite: $\mathbf{F R}_{\mathbf{g}}$ (fuel reactor gas

852 outlet) $\mathbf{A R}_{\mathbf{g}}$ (air reactor gas outlet) Pyr (pyritic sulphur in ashes) Ash (self-retention by ashes)

853

854

855

856

857

858

859

860 


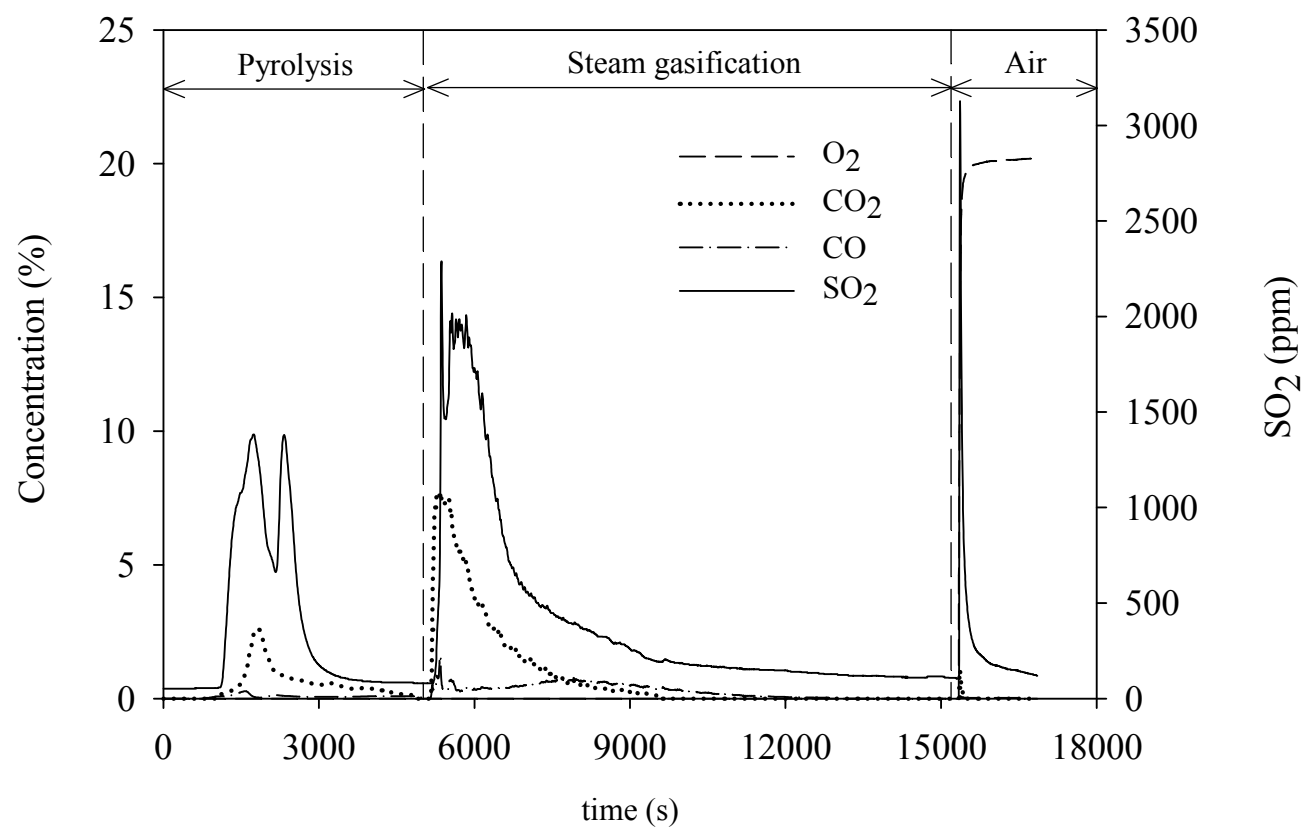

861

862 Figure 6. Evolution with time of the main products from lignite pyrolysis and steam

863 gasification at $900^{\circ} \mathrm{C}$

864

865

866

867

868

869

870

871

872

873

874

875

876

877 

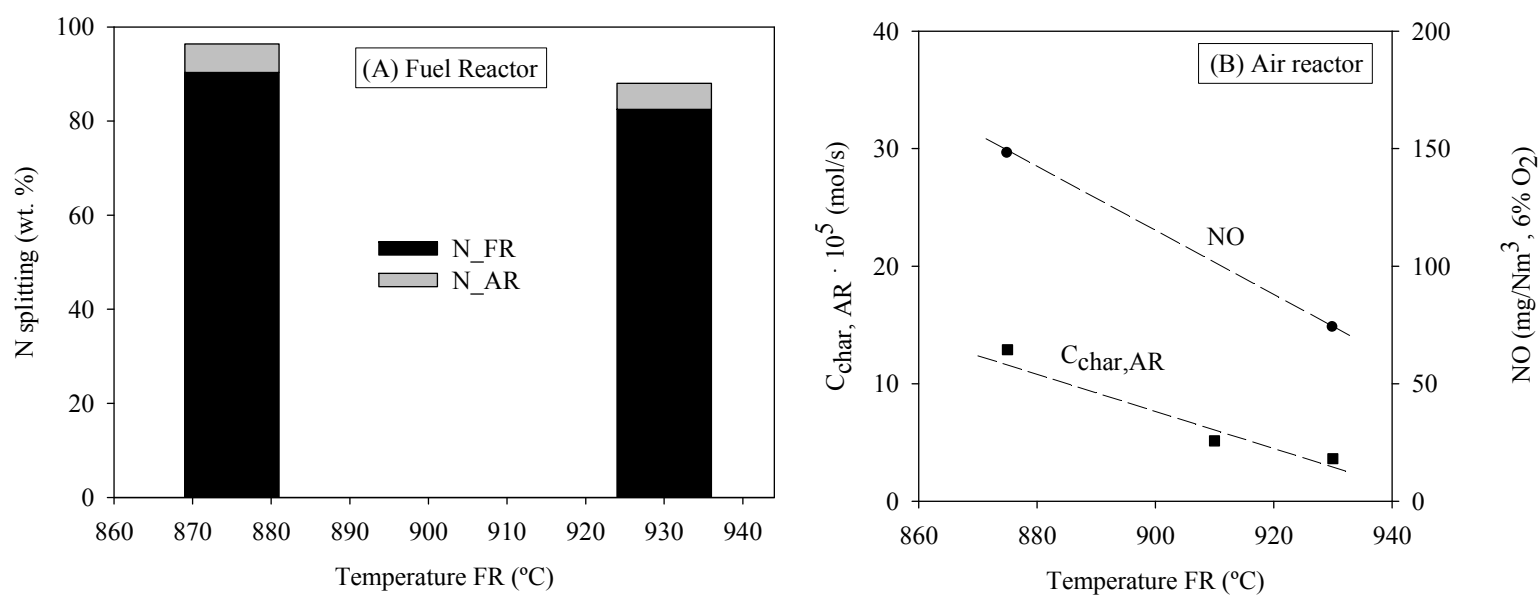

879 Figure 7. (A) Nitrogen splitting in experiments with ilmenite and lignite: $\mathbf{N} \_$FR (fuel reactor

880 gas outlet) $N_{A R}$ (air reactor gas outlet) (B) carbon molar flow and NO emissions in the air

881 reactor at different fuel reactor temperatures

882

883

884

885

886

887

888

889

890

891

892

893

894

895

896

897 


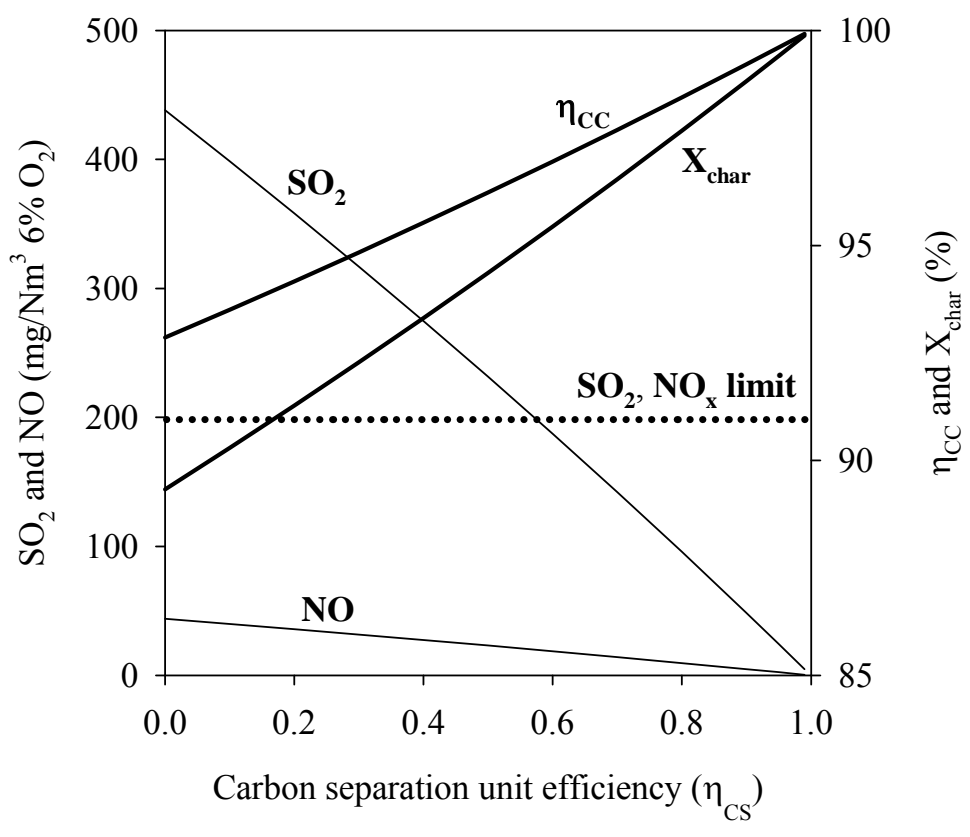

899 Figure 8. $\mathrm{SO}_{2}$ and $\mathrm{NO}$ emissions together with carbon capture efficiency and char conversion

900 for different efficiencies in the carbon separation unit in experiments with ilmenite and lignite

901 at $930^{\circ} \mathrm{C}$

902

903

904

905

906

907

908

909

910

911

912

913

914 
915 Tables

916 Table 1. Concentration of different compounds at the fuel reactor outlet

\begin{tabular}{|c|c|c|c|}
\hline Component & $\begin{array}{l}\text { DYNAMIS } \mathrm{CO}_{2} \text { quality recommendations } \\
\text { (de Visser et al., 2008) }\end{array}$ & $\begin{array}{l}\text { Present work } \\
\left(930^{\circ} \mathrm{C}\right)\end{array}$ & Units \\
\hline $\mathrm{H}_{2} \mathrm{O}$ & 500 & - & ppmv \\
\hline $\mathrm{H}_{2} \mathrm{~S}$ & 200 & 2692 & ppmv \\
\hline $\mathrm{CO}$ & 2000 & 42567 & ppmv \\
\hline $\mathrm{O}_{2}$ & $\begin{array}{l}\text { Aquifer }<4 \\
\text { EOR } 0.0001-0.001\end{array}$ & - & vol $\%$ \\
\hline $\mathrm{CH}_{4}$ & $\begin{array}{l}\text { Aquifer }<4 \\
\text { EOR }<2\end{array}$ & 1.2 & vol $\%$ \\
\hline $\mathrm{N}_{2}, \mathrm{Ar}, \mathrm{H}_{2}$ & $<4$ (all non-condensable gases) & $\begin{array}{l}0.3\left(\mathrm{~N}_{2}\right)^{\mathrm{a}} \\
2.9\left(\mathrm{H}_{2}\right)\end{array}$ & vol $\%$ \\
\hline $\mathrm{SO}_{2}$ & 100 & 11693 & ppmv \\
\hline $\mathrm{NO}_{\mathrm{x}}$ & 100 & 42 & ppmv \\
\hline $\mathrm{CO}_{2}$ & $>95.5$ & 89.1 & vol $\%$ \\
\hline
\end{tabular}

$917{ }^{a}$ Only nitrogen formed from fuel-N is considered

918

919

920

921

922

923

924

925 
926 Table 2. Main properties of activated ilmenite particles

927

\section{Activated ilmenite}

XRD phases $\quad \mathrm{Fe}_{2} \mathrm{TiO}_{5}, \mathrm{Fe}_{2} \mathrm{O}_{3}$

Crushing strength $(\mathrm{N}) \quad 3.2$

Oxygen transport capacity(\%) 4.3

Particle density $\left(\mathrm{kg} / \mathrm{m}^{3}\right) \quad 4100$

Porosity (\%) $\quad 18.7$

BET Surface $\left(\mathrm{m}^{2} / \mathrm{g}\right) \quad 0.8$

928

929

930

931

932

933

934

935

936

937

938

939

940

941

942

943 
944 Table 3. Proximate and ultimate analyses of the Spanish lignite (wt \%)

945

\begin{tabular}{llll}
\hline Carbon & 45.4 & Moisture & 12.5 \\
Hydrogen & 2.5 & Ash & 25.2 \\
Nitrogen & 0.6 & Volatile matter & 28.6 \\
Sulfur & 5.2 & Fixed carbon & 33.6 \\
Oxygen $^{\text {a }}$ & 9.9 & & \\
\hline LHV $(\mathrm{kJ} / \mathrm{kg})$ & 16252 & &
\end{tabular}

$946{ }^{\mathrm{a}}$ By difference

947

948

949

950

951

952

953

954

955

956

957

958

959

960

961

962 
963 Table 4. Equipment used in the measurement of different pollutants

964

\begin{tabular}{lll}
\hline Species & Measurement method & Instrument (supplier) \\
\hline $\mathrm{CO}, \mathrm{CO}_{2}, \mathrm{CH}_{4}$ & Nondispersive infrared & Maihak S710/UNOR \\
$\mathrm{O}_{2}$ & Paramagnetism & Maihak S710/OXOR-P \\
$\mathrm{H}_{2}$ & Thermal conductivity & Maihak S710/THERMOR \\
$\mathrm{SO}_{2}$ & Infrared & Siemens Ultramat 23 \\
$\mathrm{H}_{2} \mathrm{~S}, \mathrm{COS}, \mathrm{CS}_{2}$ & Gas chromatography & Varian 3400-CX GC (PORAPAK- \\
& & Q column) \\
& & Flame photometric detector (FPD) \\
& & Pfeiffer \\
$\mathrm{NH}_{3}, \mathrm{HCN}$ & Mass spectrometry & Temex CX 4000 \\
$\mathrm{NO}_{\mathrm{x}}$ & FTIR & VM3000 from MCI \\
$\mathrm{Hg}^{0}$ (g) & Cold vapour atomic absorption & \\
& spectroscopy & \\
$\mathrm{Hg}^{2+}($ impingers $)$ & Gold amalgam atomic absorption & LECO AMA254 \\
$\mathrm{Hg}^{2}$ (p) & spectroscopy & \\
\hline
\end{tabular}

965

966 